\title{
Lan merkatuko genero desberdintasunaren bilakaera Euskal Autonomia Erkidegoan (EAE) (2002-2020)
}

\author{
(The Evolution of Labour Market Gender Differences \\ in the Basque Country (2002-2020))
}

Patricia Peinado*

Euskal Herriko Unibertsitatea (UPV/EHU)

\begin{abstract}
LABURPENA: Bosgarren Garapen Iraunkorreko Helburuak (5. GIH) Genero Berdintasuna lortzea dauka helburu. Artikulu honetan Euskal Autonomia Erkidegoko (EAE) lanmerkatuko genero berdintasunen bilakaera deskribatzen da 2002-2020 epealdian Langabeziako Genero Arrakala (LGA), Enpleguko Genero Arrakala (EGA), Jarduerako Genero Arrakala (JGA) eta Generoaren araberako Soldata Arrakala (SGA) aztertuz. Analisia egiteko lau azpiepealdi hartzen dira kontuan: Atzeraldi Handia baino lehenagokoa, Atzeraldi Handikoa, errekuperazio ekonomikoaren epealdia eta COVID-19aren hasierakoa. Emaitzek erakusten dutenez, EAEko genero arrakalek behera egin duten arren oraindik bide luzea dago genero berdintasuna lortzeko. Horrela, bada, EAEk bereziki generoaren araberako soldata-desberdintasunak murrizteko politikak garatzea gomendatzen da.
\end{abstract}

HITZ GAKOAK: 5. GIH, Genero Berdintasuna, Lan Merkatua, EAE, Genero Arrakalak.

ABSTRACT: The aim of the Sustainable Development Goal number five is to achieve Gender Equality. In this article the evolution of gender differences in the labour market in the Basque Country is described for the period 2002-2020 by assessing the Gender Unemployment Gap (GUG), the Gender Employment Gap (GEG), the Gender Activity Gap (GAG) and the Gender Wage Gap (GWG). The analysis is performed for different subperiods of time: the period Prior to the Great Recession, the period of the Great Recession, the period of economic recovery and the beginning of COVID-19 period. Although gender gaps have diminished there is still a long path for the gender equality to be achieved. Policies aimed to close gender differences in wages are recommended for the Basque Country.

KEYWORDS: SDG5, Gender Equality, Labour Market, Basque Country, Gender Gaps.

\footnotetext{
* Harremanetan jartzeko / Corresponding author: Patricia Peinado. Euskal Herriko Unibertsitatea UPV/EHU, Sarriena auzoa, z/g (48940 Leioa). - patricia.peinado@ehu.eus - https://orcid.org/0000-0001-5494-4830

Nola aipatu / How to cite: Peinado, Patricia (2021). «Lan merkatuko genero desberdintasunaren bilakaera Euskal Autonomia Erkidegoan (EAE) (2002-2020)». Ekaia, 41, 2021, 321-339. (https://doi.org/10.1387/ekaia.22072).

Jasotze-data: 2020, irailak 29; Onartze-data: 2021, maiatzak 12.

ISSN 0214-9753 - elSSN 2444-3581 / (c) 2021 UPV/EHU
}

cc)(i) $\Theta$ Lan hau Creative Commons Aitortu-EzKomertziala-LanEratorririkGabe 4.0 Nazioartekoa lizentzia baten mende dago 


\section{SARRERA}

Nazio Batuen Erakundeak (NBE) Garapen Iraunkorreko Helburuak (GIH) definitu zituen 2015. urtean. Helburu horien artean, «Genero Berdintasuna» aurkitzen da bosgarren postuan (5. GIH) . NBEren esanetan [1], «Genero berdintasuna ez da bakarrik oinarrizko giza eskubidea; mundu iraunkor, oparo eta baketsua izateko beharrezko oinarria ere bada».

Genero berdintasuna ulertzeko ikuspuntu holista da beharrezkoa ${ }^{1}$; errealitate-ugaritasuna eta kontestu-aniztasuna kontuan hartzen duena, hain zuzen. Ikuspuntu horietatik guztietatik, ekarpen honetan jorratzen dena lan merkatukoa da. Hain zuzen, Euskal Autonomia Erkidegoko (EAE) lanmerkatuko genero ezberdintasunen bilakaera XXI. mendean zehar deskribatzea du helburu. Horretarako, lan merkatuko genero desberdintasunak neurtzeko erabiltzen diren ohiko indikatzaileak hartuko dira abiapuntu gisa. Honako hauek dira: langabeziako genero-arrakala (LGA), enpleguko genero-arrakala (EGA), jarduera genero-arrakala (JGA) eta -generoaren araberako soldata-arrakala (SGA).

Lau arrakala horiek estatistikako iturri ofizialeko datuekin kalkulatzen dira; Espainiako Estatistika Institutuaren (INEren) datuetatik, hain zuzen. Horiek erabiltzearen arrazoiak hauexek dira: i) maiztasun handiko datuak daude eskuragarri; ii) estatu mailako datuak eskaintzen dira; eta, iii) 2020. urteko datuak aurkitzen dira. Horrek guztiak laguntzen du deskribapen zabalagoa egiteko, COVID-19aren lehenengo zantzuak behatzeko eta Espainiako estatua erreferentziatzat hartuta EAEren egoera identifikatzeko.

Behatutako epea 2002-2020 urte bitartekoa da. Literaturak frogatu duen lez, lan merkatuko genero arrakalak ziklo ekonomikoari datoz lotuta [2,3]. Hori dela eta, analisia garatzerakoan lau azpiepealdi espero da nabarmentzea. Lehenengoa, 2002-2008 azpiepealdia; hau da, Atzeraldi Handia baino lehenagokoa. Bigarrena, 2009-2013 urte bitarteko epea, Atzeraldi Handiaren eraginak bereziki islatzen dituena. Hirugarrena, 2014-2019 azpiepealdia, non Atzeraldi Handiaren osteko errekuperazio ekonomikoaren aztarnak antzematen diren; eta, azkenik, COVID-19ko krisialdi berriarekin sumatu hasi berri diren lehenengo zantzuak.

${ }^{1}$ Genero berdintasunak errealitate zabal eta ugari barneratzen ditu. Izan ere, NBEk erronkak eta horiei loturiko indikatzaile anitz definitzen ditu genero berdintasuna lortzeko [1]. Erronkak zenbakituta eta izendatuta daude zerrenda honen arabera: 5.1; 5.2; 5.3; 5.4; 5.5; 5.6; 5.A; 5.B; eta 5.C. Horietatik, herrialde bakoitzak edota instituzio zehatzak identifikatu eta aukeratu ahal ditu testuinguru espezifikoan erronkatzat hartu ahal direnak baita horiei loturiko indikatzaileak ere. 
Komenigarria da azpimarratzea ekarpen honen helburua ez dela genero arrakalak ulertzea edota azpiko faktoreak neurtzea. Lanaren helburu nagusia da, ordea, EAEko genero DESberdintasunen bilakaera deskribatzea, lan merkatuko genero desberdintasunen bilakaera abiapuntutzat hartuta. Edonola, historian zehar genero arrakalak azaltzeko eta ulertzeko garatu diren teoriak aipatuko dira.

Azpimarratzekoa ere bada genero berdintasuna bihurtzen dela bereziki garrantzitsua COVID-19aren testuinguruan. Izan ere, NBEk argitaraturiko azken txostenaren arabera, COVID-19ak geldiarazi ez ezik, okerragotu ere egin ditu orain arte erdietsi diren lorpenak [4]. Beraz, lehenengo aztarnak identifikatzea, ekarpen honetan eskaintzen den legez, ezinbesteko informazioa izango da etorkizuneko politika gidalerroak definitzerakoan.

Lana honela egituratuta dago: bigarren atalean lan merkatuko genero desberdintasunak azaltzeko erabiltzen diren teoriak laburtzen dira; hirugarren atalean ikerkuntzan erabilitako datuak eta metodologia azaltzen dira laugarren atalean ikerkuntzaren emaitzak eskaintzen dira, bosgarren atalean, eztabaida eta ekarpenaren ondorio nagusiak azalduko dira.

\section{GENERO DESBERDINTASUNAK AZALTZEKO TEORIAK}

Lan merkatuko genero desberdintasunak identifikatu eta neurtu zirenetik, lan ugari argitaratu dira horiek guztiak azaltzeko asmoarekin [5, 14]. Blau eta Khan-en ekarpena [11] bereziki lagungarria da argitalpen hauetan guztietan garatutako teoriak laburtzerako orduan. Izan ere, egileek soldata arrakala azaltzeko argitaratu diren lanak identifikatu, laburtu eta sailkatzen dituzte. Egileen esanetan genero desberdintasunak azaltzeko faktoreak hiru motatan multzokatu ahal dira ${ }^{2}$ : i) ohiko faktoreak edo faktore «tradizionalak»; ii) giza araudiak, ezaugarri psikologikoak eta bestelako trebetasun ez-kognitiboak; eta, iii) eskaintzaren eta eskariaren arloko faktoreak.

\footnotetext{
2 Faktoreak bereziki generoaren araberako soldata-arrakalari lotuta agertzen zaizkio; izan ere, soldata-arrakalak jaso du ikerkuntzaren arretarik nagusiena.
} 


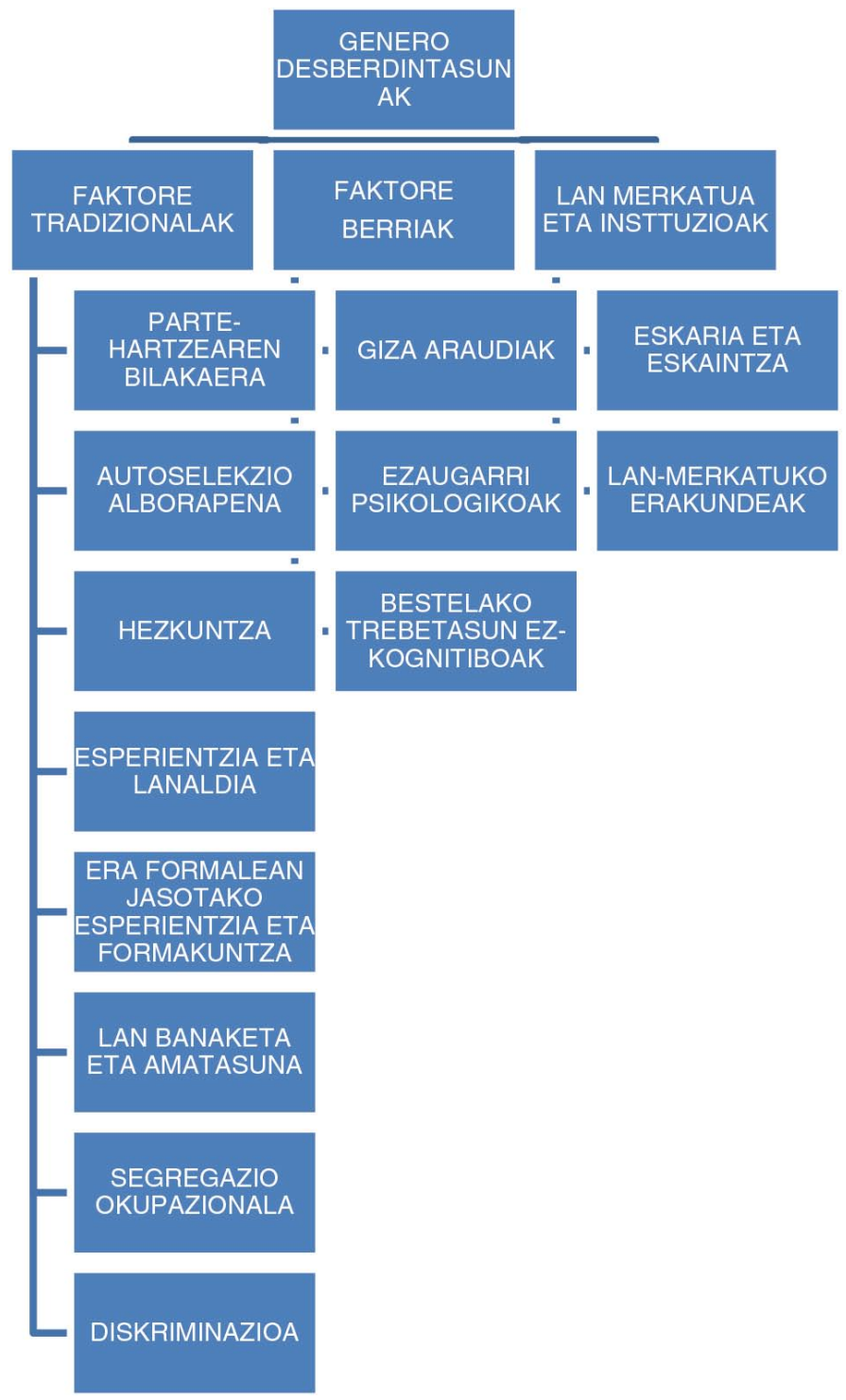

1. eskema. Lan Merkatuko Genero Arrakala azaltzeko faktoreen sailkapena.

\subsection{Ohiko faktoreak edo faktore tradizionalak}

Faktore hauek guztiek lan merkatuko genero desberdintasunak ikastea dute abiapuntu. Horien artean, identifikatzen dira: i) emakumeen parte-har- 
tzearen bilakaera lan merkatuan; ii) emakumearen autohautespenaren alboratzea; iii) emakumearen hezkuntza mailaren bilakaera; iv) lan-esperientzia eta lanaldiaren iraupena (lanean jarduniko ordu kopurua); v) era formalean lanean jasotako formakuntza eta errotazioa; vi) lan-banaketa eta amatasuna; vii) segregazio okupazionala; eta, azkenik, viii) genero-diskriminazio ilegala.

Lehenengo faktoreari dagokionez, literaturak $[15,17]$ frogatu du emakumearen parte-hartzea lan merkatuan handitu dela bereziki beste bi faktoreei lotuta; alde batetik, emakumeak jasotako soldata handitzeari lotuta eta, beste aldetik, hezkuntza-maila handitzeari lotuta. Era berean, etxeko lanak egiteko ordezkoen garapena, etxerako teknologia-aurrerapenek eta jaiotza kontrolerako pilulak, horiek guztiek erraztu dute emakumea lan merkatuan parte-hartzea. Gainera, parte-hartzea azaltzeko beharrezkoa da kontuan hartzea aukera pertsonalaren aldakuntza eta bilakaera eta baita beste faktore batzuk ere, neurtu ezin direnak.

Bigarren faktorea datu estatistikoei lotuta dago [18]. Izan ere, bakarrik behatu ahal dira formalki lan merkatuan parte hartzen duten emakumeon soldatak. Hau da, era informalean edo parte hartzen ez dutenen soldatak ezin dira identifikatu. Soldata-arrakala neurtzeko eskainitako soldatak identifikatu behar izango dira. Hori dela eta, autohautespenaren alboratzea aurkitzen da; nahiz eta alboratzearen balioa oraindik eztabaidan izan.

Hirugarren faktorea hezkuntzari lotuta dago. Historian zehar gizonak izan dira hezkuntza maila altuago lortzeko aukera izan dutenak [19]. Horrela, soldata-arrakala hezkuntza-maila desberdintasunei lotuta azaldu ahal zen. Azken urteotan, aldiz, emakumeak gizona gainditu du hezkuntza-mailetan. Gertaera hau azaltzeko teoria argirik lortu ez arren [11], bai onartu da fenomeno honen existentzia mundu mailan; hau da, emakumeen eta gizonen arteko hezkuntza-arrakalaren murriztapena nazioarte mailan.

Beste alde batetik, lan merkatuko esperientzia eta lanaldia edo lanean jarduniko ordu kopurua (laugarren faktorea) gakoak dira genero-arrakala azaltzeko orduan. Emakumeak, familia zaintzeko lanak direla eta, lan karrera laburragoa eta aldi gehiagotan moztuta izaten du. Hori dela eta, pilatutako giza kapitala txikiagoa da (gizonak duenarekin konparatuta) eta, honekin batera, emakumeak soldata maila baxuagoa izan ohi du. Nolanahi ere den, azken ekarpenek argudio honen garrantzia leuntzen dute [20]. Aldiz, beste egile batzuen esanetan, giza kapitalari lotuta izan ezean, lanaren malgutasunari atxiki ahal zaio laugarren faktore honi loturiko soldataren desberdintasuna [21]. Are gehiago, azken argudio hau mantendu ahal da soldata banaketa-funtzioaren maila altuenetan ere.

Bosgarren faktorea enplegu-aldaketari lotzen zaio. Literaturak frogatu duen arren, ceteris paribus, lan-aldaketaren probabilitatea desberdina da 
emakumeon eta gizonen artean; familia ardurak direla eta, lanari uko egiteko, gizonak baino probabilitate handiago du emakumeak. Era berean, emakumeak ez-enplegu egoeratik irteteko probabilitatea baxuagoa erakusten du [22]. Hori dela eta, emakumeak lanean jasotako formakuntza formala gizonak jasotakoa baino txikiagoa da. Horrekin batera, emakumearen giza kapitala ez da gizonarena beste handitzen, eta, ondorioz, emakumearen soldata gizonarena baino baxuagoa agertzen da.

Seigarren faktore tradizionala lan merkatuko banaketa eta amatasuna da. Amatasunak soldata penalizazioa berekin du. Hau da, seme-alaben kopurua handitu ahala, orduan eta soldata baxuagoa du emakumeak. Bi ikuspuntu desberdinetatik azaldu ahal da aurkitutako penalizazioa: i) emakumeak amatasunaren ondoren garatutako lanak soldata txikiagoa atxikita izatea promozioari uko egiteagatik edo bestelako errenuntzioei lotuta [23]; eta, ii) lan merkatuko diskriminazioa egotea kontratazioan ama diren emakumeak ama ez direnen aurrean zigortuz [24]. Azken argitalpenen esanetan, gainera, aurkitu da emakumearen soldata txikiagoa izatearen arrazoia azaldu ahal dela baita lanaren kokapen geografikoa kontuan harturik ere. Hau da, gizona soldata altuena duena izanik, familia bizi ohi da gizonaren lantokitik ahalik eta gertuen, eta, lanari uztekotan, emakumeak utzi ohi dio lan egiteari.

Genero-arrakala azaltzeko, segregazio okupazionalaren garrantzia (zazpigarren faktorea) frogatzen duten argitalpen ugari dago. Aurkitu da, egun, emakumeak soldata baxuenetako okupazioetan izateak arrakalaren herena azaltzen duela [11].

Azkenik, zortzigarren faktorea, azaldu barik gelditzen den arrakalaren zatia lan merkatuko legez kanpoko [25] diskriminazioari lotzen zaio [26] edota tradizionalak ez diren beste faktoreei. Horien artean, 2.2. eta 2.3 azpiataletan laburtzen direnak.

\subsection{Giza araudiak, ezaugarri psikologikoak eta bestelako trebetasun ez-kognitiboak}

Hainbat ikerketaren arabera [27-29], emakumeak negoziaziorako eta lehiarako joera txikiagoa du gizonarekin alderatuta; are gehiago, emakumeak arriskuari abertsio handiagoa dio. Faktore hauek guztiek azaldu ahal dute zergatik emakumearen soldata baxuagoa den, baita zergatik ez duen horrenbesteko parte-hartzerik goi-mailako lanpostuetan ere. Hala eta guztiz ere, Blau eta Kahn-ek [11] azaltzen duten lez, kontuan hartu behar da naturaren eta «nurture»aren arteko desberdintasuna; hau da, zer ezin den aldatu eta zer aldatu ahal den hezkuntzaren bitartez. Gainera, beste ezaugarri batzuk ere baditu emakumeak, gizonengan aurkitzen ez direnak. Esaterako, jendearekiko harreman interpertsonalak garatzeko gaitasunak. Hau da, giza araudiak, ezaugarri psikologikoak eta bestelako trebetasun ez-kog- 
nitiboek txartu edo hobetu ahal dute bai emakumearen soldata baita gizonarena ere, faktore konkretuen edota testuinguruaren arabera. Are gehiago, teoria hauek guztiek aurkitutako ebidentzia enpiriko gehiena laborategian egindako esperimentuen ondorio da. Horrek kolokan jartzen du emaitzen zabalkuntzaren egokitasuna; hau da, ale konkretu batean aurkitutako emaitza izan ahal da lagungarria baino agian ez du azaltzen gizartean osotasunez gertatutakoa. Nolanahi ere den, faktore psikologikoek soldata-arrakalaren tarte ertain edo txiki bat baino ez dute azaltzen.

\subsection{Eskaintzaren eta eskariaren arloko faktoreak}

Ikuspuntu mikroekonomikotik, hau da, gizabanakoen edo enpresen erabakien ondorioak behatzen direnean, soldata-arrakalak badauka aurreko faktoreetan (tradizionalak edo ez tradizionalak) oinarritutako azalpena. Aitzitik, agente sozialak testuinguru makroekonomikoan daude barneratuta; hau da, lan merkatuko eskaintza, lan merkatuko eskaria eta lan merkatuari loturiko instituzioak ere badaude. Hori dela eta, azken horiek guztiek genero-arrakala azal dezakete.

Horren harira, ikerkuntzak frogatu du soldata-egiturak eragina duela gizabanako talde batzuen soldata definitzeko orduan [30]. Sindikatuak dituzten herrialdeetan, non formakuntza gutxiagoko langileen soldatak defendatzen diren, soldata-egitura murriztuago aurkitzen da [8]. Hau da, soldata-zorua erlatiboki altuagoa da. Horrekin batera, genero-arrakala txikiagoa da. Izan ere, emakume gehiago aurkitzen dira soldata banaketa funtzioaren hasieran (soldatarik txikiena aurkitzen den zatian). Aldiz, sindikatuen esku-hartze txikiko herrialdeetan soldata egitura zabalagoa da. Azken herrialde hauetan genero-arrakala handiagoa izan ohi da. Aitzitik, sindikatu zentralizatuegiko herrialdeetan emakumearen enplegu erlatiboa jaistearen aztarnak ageri dira; izan ere, horrelako instituzioen presentzia enpleguaren beherakadarekin eta langabeziaren gorakadarekin lotuta dago [31].

\section{METODOLOGIA ETA DATUAK}

\subsection{Metodologia}

Lan merkatuko genero desberdintasunen bilakaera deskribatzeko eta alderatzeko bi indikatzaile mota erabiltzen dira. Alde batetik, genero-arrakalak kalkulatzen dira. Beste aldetik, genero-arrakala guztien hazkunde tasa kalkulatzen da azpiepealdi bakoitzeko. Lehenengo indikatzaileek genero desberdintasunak neurtzen laguntzen dute. Bigarrenek, genero desberdintasunen horien bilakaeraren abiadura zenbatestea dute helburu. 


\subsubsection{Genero Arrakalak Lan Merkatuan}

Lan merkatuko genero arrakalen artean, Langabeziaren arloko Genero Arrakala (LGA), Enpleguko Genero Arrakala (EGA), Jarduerako Genero Arrakala (JGA) eta Generoaren araberako Soldata Arrakala (SGA) aurkitzen dira.

Langabeziako Genero Arrakalak (LGA) langabeziaren barruan emakumeen eta gizonen artean gertatzen diren desberdintasunak neurtzen ditu. LGA neurtzeko honako (1) ekuazio hau erabiltzen da:

$$
\mathrm{LGA}_{t}=l_{t}^{e}-l_{t}^{g}
$$

Non LGA $_{t}-\mathrm{k} t$ urtean Langabezian dagoen Genero Arrakala adierazten duen, $l_{t}^{e}$ emakumeentzat $t$ urteko langabezia tasa den eta $l_{t}^{g}$ gizonentzat $t$ urteko langabezia tasa den.

Enpleguko Genero Arrakalak (EGA) enpleguan gizon eta emakumeen artean gertatzen diren desberdintasunak neurtzen ditu enpleguan. Enplegu-arrakala neurtzeko ondoren azaltzen den (2) ekuazioa erabiltzen da:

$$
\mathrm{EGA}_{t}=e_{t}^{g}-e_{t}^{e}
$$

Non EGA $t$ - $\mathrm{k} t$ urtean Enpleguan sortutako Genero Arrakala adierazten duen, $e_{t}^{g}$ gizonentzat $t$ urteko enplegu tasa den eta $e_{t}^{e}$ emakumeentzat $t$ urteko enplegu tasa den.

Jarduerako Genero Arrakalak (JGA) gizon eta emakumeen artean jardueran dauden desberdintasunak neurtzen ditu. Jarduera-arrakala neurtzeko hurrengo (3) ekuazioa erabiltzen da:

$$
\mathrm{JGA}_{t}=j_{t}^{g}-j_{t}^{e}
$$

Non JGA $\mathrm{A}_{t}-\mathrm{k}$ Jardueran $t$ urtean gertatutako Genero Arrakala adierazten duen, $j_{t}^{g}$ gizonentzat $t$ urteko jarduera tasa den eta $j_{t}^{e}$ emakumeentzat $t$ urteko jarduera tasa den.

Generoaren araberako Soldata Arrakalak (SGA) gizon eta emakumeen arteko soldaten arteko desberdintasunak neurtzen ditu gizonen soldaten ehunekotan. Soldata-arrakala neurtzeko honako (4) ekuazio hau erabiltzen da.

$$
S G A_{t}=\frac{s_{t}^{g}-s_{t}^{e}}{s_{t}^{g}} 100
$$

Non $S G A_{t} t$ urteko Soldata Arrakala adierazten duen, $s_{t}^{g}$ gizonentzat $t$ urteko soldata den eta $s_{t}^{e}$ emakumeentzat $t$ urteko soldata den. 


\subsubsection{Genero Arrakalen Bilakaera: Hazkunde Tasak}

Behin genero-arrakalak identifikatuta posible da horien bilakaeraren neurria zenbatestea. Horretarako, arrakala bakoitzaren hazkunde tasa kalkulatu ahal da azpiepealdi bakoitzeko.

Ondoren azaltzen dira arrakala bakoitzaren hazkunde tasaren balioespenean erabilitako formulak.

Langabeziako Genero Arrakalaren hazkuntza tasa kalkulatzen da (5) formula honi jarraituz:

$$
L \dot{G} A_{t, t-1}^{i}=\frac{\left(L G A_{t}^{i}-L G A_{t-1}^{i}\right)}{L G A_{t-1}^{i}} 100
$$

Non $L \dot{G} A_{t, t-1}^{i}-\mathrm{k}(t-1)$ eta $t$ urte bitarteko langabeziako genero-arrakalaren hazkuntza tasa adierazten duen $i$ lurraldean; $L G A_{t-1}^{i} i$ lurraldeko langabeziaren arloko genero-arrakala den $(t-1)$ urtean; eta, $L G A_{t}^{i} i$ lurraldeko langabeziaren arloko genero-arrakala den $t$ urtean.

Enpleguko Genero Arrakalaren Hazkuntza tasa kalkulatzen da (6) formula honi jarraituz:

$$
E \dot{G} A_{t, t-1}^{i}=\frac{\left(E G A_{t}^{i}-E G A_{t-1}^{i}\right)}{E G A_{t-1}^{i}} 100
$$

Non $E \dot{G} A_{t, t-1}^{i}(t-1)$ eta $t$ urte bitarteko enpleguko genero-arrakalaren hazkuntza-tasa adierazten duen $i$ lurraldean; $E G A_{t-1}^{i} i$ lurraldeko enplegu arloko genero-arrakala den $(t-1)$ urtean; eta, $E G A_{t}^{i} i$ lurraldeko enplegu arloko genero-arrakala den $t$ urtean.

Jarduerako Genero Arrakalaren Hazkuntza tasa (7) formulari jarraituz kalkulatzen da:

$$
J \dot{G} A_{t, t-1}^{i}=\frac{\left(J G A_{t}^{i}-J G A_{t-1}^{i}\right)}{J G A_{t-1}^{i}} 100
$$

Non $J \dot{G} A_{t, t-1}^{i}-\mathrm{k}(t-1)$ eta $t$ urte bitarteko jarduera arloko genero-arrakalaren hazkuntza-tasa adierazten duen $i$ lurraldean; $J G A_{t-1}^{i} i$ lurraldeko jarduera arloko genero-arrakala den $(t-1)$ urtean; eta, $J G A_{t}^{i} i$ lurraldeko jarduera arloko genero-arrakala den $t$ urtean.

Generoaren araberako Soldata Arrakalaren Hazkuntza tasa (8) formulari jarraituz kalkulatzen da:

$$
S \dot{G} A_{t, t-1}^{i}=\frac{\left(S G A_{t}^{i}-S G A_{t-1}^{i}\right)}{S G A_{t-1}^{i}} 100
$$


Non SGंA $\mathrm{A}_{t, t-1}^{i}(t-1)$ eta $t$ urte bitarteko generoaren araberako soldata-arrakalaren hazkuntza-tasa adierazten duen $i$ lurraldean; $\mathrm{SGA}_{t-1}^{i} i$ lurraldeko generoaren araberako soldata-arrakala den $(t-1)$ urtean; eta, EGA ${ }_{t}^{i} i$ lurraldeko generoaren araberako soldata-arrakala den $t$ urtean.

\subsection{Datuak}

Aipatutako definizioak abiapuntu harturik, horien bilakaera Espainiako Estatistika Institutuak (INEk) eskaintzen dituen datuak baliatuz aztertzen da goiko formulen balioak kalkulatuz baita arrakalen bilakaera irudikatuz. Hain zuzen, Biztanleria Aktiboa Inkestatik (BAI) eta Soldata Egitura Inkestatik (SEI) jasotakoak. Lehengo inkestako (BAI) datuekin langabezia-, enplegu- eta jarduera-arrakalak kalkulatu dira. Bigarren inkestako (SEI) datuak, soldata-arrakala kalkulatzeko erabili da.

Lanaren helburua EAEko lan merkatuan emandako genero desberdintasunen bilakaera aztertzea izanik, aipatutako inkestetan eskuragarri dauden beste urteetako datuak hartu dira. Hain zuzen, 2002-2020 epealdirako datuak erabili dira langabezia-, enplegu- eta jarduera-arrakalak deskribatzeko. Soldata-arrakalaren bilakaera, aldiz, bakarrik aztertu ahal da 20082017 epealdirako, beste urteetako daturik eza dela eta.

Epealdi osoa lau azpiepetan zatitu da. Lehenengoa Atzeraldi Handia baino lehenagoko epealdia; hau da, 2002-2008 urte bitartekoa. Bigarrena, Atzeraldi Handiko garaikoa, 2009-2013 bitatekoa. Hirugarrena, COVID19a baino lehenagoko epealdia, 2014-2019 artekoa, eta, azkenik, 2020. urterako eskuragarri dauden datuak aztertuko dira azken COVID-19aren krisi honen eraginaren norabidea identifikatzeko.

\section{EMAITZAK}

\subsection{Langabeziako Genero Arrakala (LGA)}

1. irudian Langabeziako Genero Arrakala (LGA) irudikatzen da 20022020 epealdirako EAEko eta Espainiako estatuan. Datuei erreparatuz LGAren bilakaera kontraziklikoa dela ondorioztatzen $\mathrm{da}^{3}$. Hau da, atzeraldietan langabezia-arrakala murrizten den bitartean, hedaldietan langabeziaarrakalaren balioa handitzen da. Fenomeno hau bi lurraldeetan antzematen da. Azterturiko epealdian, hain zuzen, bi ziklo ekonomikoen aztarnak identifikatzen dira: i) 2002-2008 urte bitarteko hedaldiaren epealdia, non bai

\footnotetext{
3 Arrakalaren bilakaera kontraziklikoa ikasi da hainbat argitalpen irakurrita [2,3]. Ikerkuntzek arrakalaren beherakada gizonaren egoeraren txartzearekin lotzen dute eta ez hainbeste emakumearen egoera hobetzearekin.
} 
EAEn baita Espainiako estatuan ere, langabezia-arrakalek balio positibo esanguratsuak islatzen dituzten; ii) Atzeraldi Handiaren garaia, 2009-2013, non langabezia arrakalek balio minimoak erdiesten dituzten; iii) errekuperazio ekonomikoaren urteak, 2014-2019, non hedaldiaren zantzuak diren nabarmen langabezia-arrakalen balioak handitzearekin batera bi lurraldeetan; azkenik beherakada nabaritzen da Espainiako estatuan nahiz eta oraindik EAEko kasuan ez aurkitu.

Epealdiari osotasunez erreparatzean ondoriozta daiteke langabeziaarrakala murriztu egin dela bai EAEn baita Espainiako estatuan ere. Beherakadaren balioa, aitzitik, ez da berdina izan. Espainiako estatuan 2002tik 2020ra langabezia-arrakala \% 56.82 txikitu den bitartean, EAEn aurkitutako langabezia-arrakala \% 86.45 txikitu da. Hori dela eta, nahiz eta epealdiaren hasieran EAEn izandako langabezia-arrakala Espainiako estatuan baino altuagoa izan (8.19 vs. 7.99), epealdiaren amaieran EAEko langabezia-arrakalak Espainiako estatuan baino askoz balio baxuago erakusten du. Hain zuzen EAEko langabezia-arrakala Espainiako estatuan aurkitutakoaren herena izanik 2020. urtean; 1.11 eta 3.45 balioekin, hurrenez hurren. Hau da, EAEn egungo langabeziak ia ez du genero-arrakalarik; ondorioz, genero berdintasuna helburutik gertu dago (zerotik gertu izanik 1.11 (puntu portzentualeko (pp) balioarekin)). Are gehiago, bi lurraldeak alderatzean ondorioztatzen da EAEko langabezia-arrakala Espainiako estatuan baino txikiagoa dela orokorrean. Izan ere, bi urtetan izan ezik (2002. eta 2010. urteak), behaturiko beste urte guztietan EAEko langabezia-arrakalak Espainiako estatuaren aurrean balio esanguratsu baxuagoa izan du.

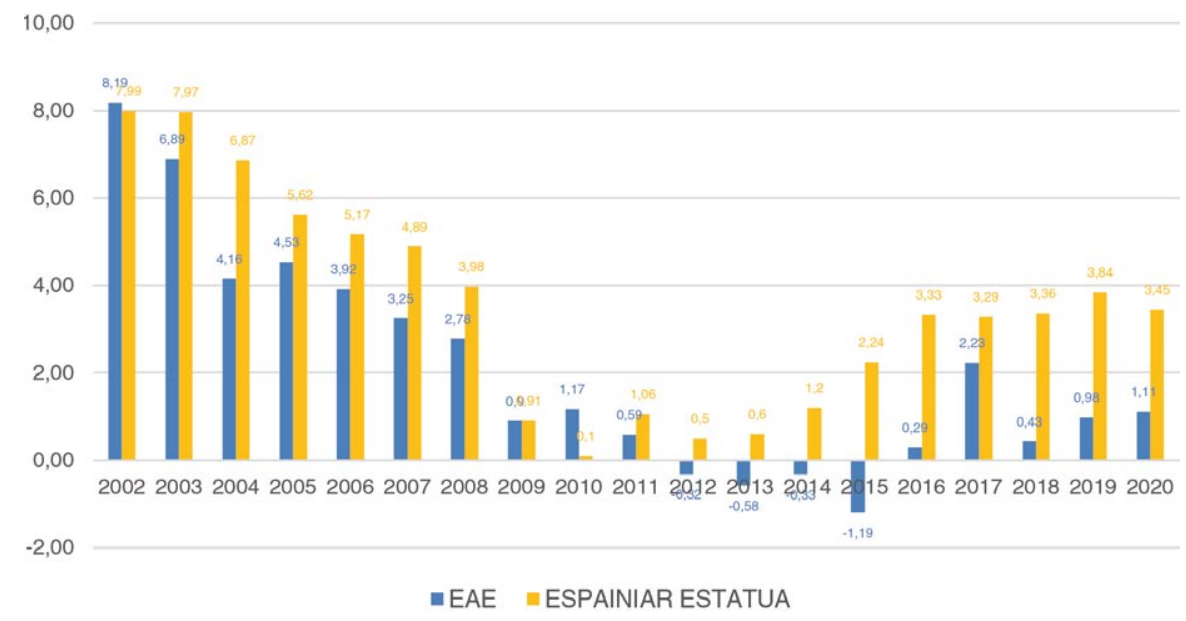

1. irudia. Langabeziako Genero Arrakalaren (LGA) bilakaera EAEn eta Espainiako Estatuan (2002-2020). 
Hortaz, datuek argi erakusten dute EAEn langabezian aurkitutako genero desberdintasunak txikiagoak direla Espainiako estatuarekin alderatuta. Horrek, EAEn posizio altuago batean kokatzen du Nazio Batuen Erakundeak (NBE) definitutako Bosgarren Garapen Iraunkorreko Helburua (5. GIH) lortzeko rankingean; hain zuzen ere, Langabeziako Genero Arrakala (LGA) behatzean aurkitzen denaren arabera.

\subsection{Enpleguko Genero Arrakala (EGA)}

2. irudian Enpleguko Genero Arrakala (EGA) irudikatzen da 20022020 epealdirako EAEn eta Espainiako estatuan. Irudian ageri da enpleguko arrakala era esanguratsuan murriztu dela hala EAEn nola Espainiako estatuan. Izan ere, hasieran, hau da, 2002. urtean EAEko enplegu-arrakalak 24.77 balioa erakusten du, Espainiako estatuko balioa 25.91 izanik. Aldiz, epealdiaren amaieran (2020. urtean), balioak 7.95 eta 11.07 dira, hurrenez hurren. Beraz, datuek islatzen duten bezala, EGAk behera egin du EAEn $\% 67.90$ eta Espainiako estatuan \% 57.28.

Beherakaden abiadura, bestalde, ez da berdina izan bi lurraldeetan. Lehenengo epealdian (2002-2008) bilakaeren antzekotasuna ageri da. Izan ere, EAEn enplegu-arrakalak behera egiten du urteko \% 4.41eko tasan batez beste, Espainiako estatuan \% 4.49ko tasan egiten duen bitartean. Atzeraldi Handiaren garaian bi lurraldeetan antzematen da enpleguko arrakala-beherakaden ${ }^{4}$ azelerazioa. Urteko batez besteko balioak izanik -12.03 EAEn eta -13.25 Espainiako estatuan. Errekuperazio ekonomikoaren epealdian, aitzitik, lurraldeen elkar-joera galtzen da. Izan ere, 2014-2019 epealdian EAEn enplegu-arrakalak murrizten jarraitzen du (\% 3.61 batez besteko tasan, hain zuzen); Espainiako estatuan, berriz, enplegu-arrakala batez besteko tasan \% 3.40 handitzen da. Azkenik, COVID-19aren zantzuak ikusgarriak dira EAEn non enplegu-arrakala \% 7.29 handitu den, eta Espainiako estatuan \% 4.40 murriztu.

Hau guztia kontuan harturik, hiru ondorio nagusi atera ahal dira enpleguko genero-arrakalari lotutakoak. Lehenengoa, enplegu-arrakalak txikitu dira bai EAEn baita Espainiako estatuan ere. Bigarrena, EAEn jasandako enplegu-arrakala Espainiako estatuak islatzen duena baino baxuagoa da. Hain zuzen, azterturiko 2002-2020 epealdian ia bat eta erdi portzentaje-puntua (pp) baxuagoa da ( $-1.45 \mathrm{pp})$ batez beste. Hirugarrena eta azkena, lehenengo bi epealdietan bai EAEn baita Espainiako estatuan ere enpleguarrakala murriztu da abiadura kontraziklikoan. Hau da, hedaldietan beherakada motelagoa izan da eta atzeraldietan arinagoa. Hala eta guztiz ere, Atzeraldi Handiaren amaieran patroiak aldatzen dira. Espero bezala, EAEn

${ }^{4}$ [32] lanak aurkitzen du enplegu-arrakalaren beherakada esanguratsua Europa Batasunean (EB) hezkuntza bilakaera eta BPGari lotuta dagoela. 
enplegu-arrakala murrizten den bitartean tasa baxuago batean (beherakadaren abiadura kontraziklikoa dela eta), Espainiako estatuan, espero ez den bezala, EGA handitzen da. Are gehiago, COVID-19aren aztarnak bai identifikatzen dira EAEn, non enplegu-arrakala handitzen den (\% 7.29), baina ez dira nabarmentzen oraindik Espainiako estatuan, non arrakalak oraindik beherako joera islatzen duen ( $\% 4.40)$.

Enplegu-arrakalako datuen arabera, beraz, EAEko posizioa eta bilakatzeko era ere, Espainiako estatuan aurkitutakoa baino gertuago dago NBEk definituriko 5. GIHtik; hau da, genero berdintasunetik.

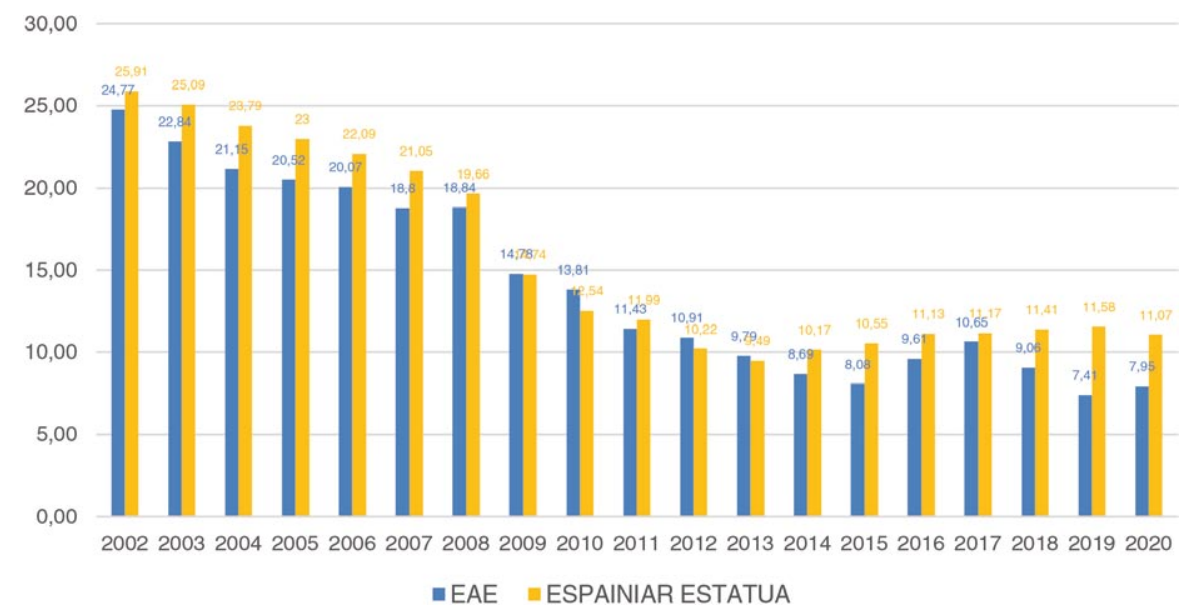

2. irudia. Enpleguko Genero Arrakalaren (EGA) bilakaera EAEn eta Espainiako Estatuan (2002-2020).

\subsection{Jarduerako Genero Arrakala (JGA)}

3. irudian Jarduerako Genero Arrakala (JGA) irudikatzen da 20022020 epealdirako EAEn eta Espainiako estatuan. Aurreko irudian enplegurako aurkitu den bezala, 3. irudi honetan jarduera-arrakalaren joera negatiboa antzematen da; hau da, balioa txikitu egin da urteetan zehar. Epealdiaren hasieran, 2002 urtean, jarduera-arrakalak 22.59 balio zuen EAEn eta 2.02 puntu gehiago Espainiako estatuan, 24.61 pp-ko balioa izanik. Urteetan zehar arrakalaren beherakada esanguratsua antzematen da. Hain zuzen, EAEn arrakalaren balio berria 2020 urtean, 8.03koa da; arrakalaren \% 64.45 beherakada adierazten duena. Espainiako estatuko arrakalaren murriztapena txikiagoa da EAEko kasuaren aurrean. Izan ere, Espainiako estatuan arrakalaren balioa \% 56.93 jaisten da, 10.60 pp-ko balioa erdietsiz. 


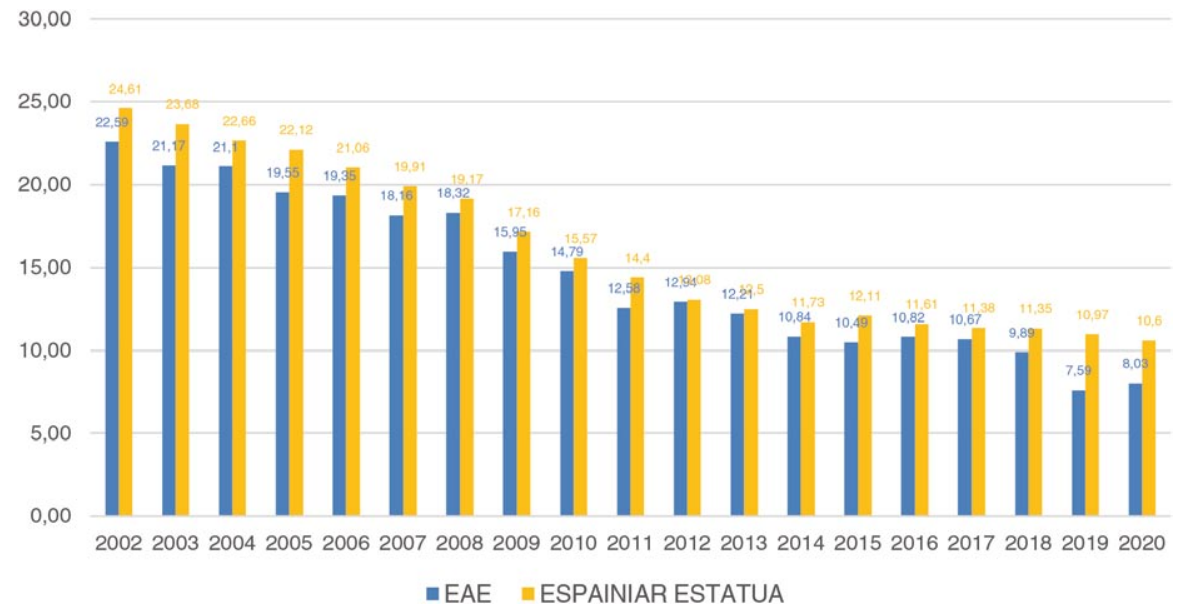

3. irudia. Jarduerako Genero Arrakalaren (JGA) bilakaera EAEn eta Espainiako Estatuan (2002-2020).

EAEko jarduera-arrakala Espainiako estatukoa baino txikiagoa da epealdi osoan zehar 0.14 eta 3.38 pp bitarteko balio txikiagoa erakutsiz. Batez beste, 2002-2020 urteen bitartean EAEko jarduera-arrakala Espainiako estatuko baino $1.51 \mathrm{pp}$ txikiagoa da.

Arrakalaren bilakaerari dagokionez, ziklo ekonomikoaren fase desberdinetan zehar,, azpimarratzekoa da enplegu-arrakalan aurkitutakoa mantentzen dela. Hau da, arrakalaren aldakuntzaren bilakaera kontraziklikoa da. Izan ere, hedaldietan arrakalaren eboluzio negatiboa motelagoa da atzeraldi garaietan aurkitutakoarekin alderatuta. Zehazki, 2002-2008 epealdian, batez bestez, arrakala \% 3.38 murrizten da EAEn eta \% 4.07 Espainiako estatuan. Atzeraldi Handiko epealdian EAEn \% 7.59ko tasan txikitzen da; Espainiako estatuan, berriz, 8.17ko tasan murrizten da. Errekuperazio ekonomikoaren urteetan (2014-2019) EAEn jarduera-arrakala txikitzen da, bataz beste, \% 7.21. Espainiako estatuan, aitzitik, \% 2.11ko beherakada antzematen da. Azkenik, COVID-19a heltzearekin batera, EAEn jarduera-arrakala handitzen da \% 5.80, eta Espainiako estatuan txikitzen jarraitzen du; hain zuzen, \% -3.37ko tasan.

Jarduera-arrakala bi horien bilakaera, enpleguan aurkitutakoaren antzekoa izatea espero den emaitza da. Izan ere, jarduerak bi lan merkatuko fenomenoen batura da: enplegua eta langabezia, hain zuzen. Hori dela eta, enpleguan aurkitutakoa islatzea dauka jarduera arrakalak, neurri bateraino. Kasu honetan, jarduera arrakalen bilakaerei erreparatuz gero ondoriozta daiteke antzekotasun handia duela enplegu-arrakala biekin .

Jarduera-arrakalak erakusten duen lez, eta enpleguan aurkitu bezala, EAEk berdintasun maila altuagoa erakusten du Espainiako estatuarekin al- 
deratuta. Hori dela eta, berriro ere jardueran EAEko posizio altuago edo aurreratuagoan aurkitzen da NBEk definituriko 5. GIH lortzeko bidean.

\subsection{Generoaren araberako Soldata Arrakala (SGA)}

4. irudian Generoaren araberako Soldata Arrakala (SGA) irudikatzen da 2008-20175 epealdirako EAEn eta Espainiako estatuan.

Datuak behatzean hiru ondorio nagusi atera ahal dira. Lehenengoa, EAEko soldata-arrakala ${ }^{6}$ Espainiako estatukoa baino altuagoa dela azterturiko epealdi osoan. Hau da, EAEn emakumearen soldata gizonaren soldatatik urrunago dago, Espainiako estatuan jasandako diferentziarekin alderatuta. Gainera, komeni da azpimarratzea arrakala kalkulatzean ehunekoak hartzen direla kontuan; hau da, generoaren araberako soldata-arrakala, langabezia-, enplegu- eta jarduera-arrakalak ez bezala, gizonezkoen soldaten portzentajeetan daude adierazita ${ }^{7}$. Hain zuzen, azterturiko epealdian EAEko soldata-arrakala, batez beste, Espainiako estatukoa baino $1.21 \mathrm{pp}$ handiagoa izan da.

Bestalde, soldata-arrakalaren bilakaera ziklo ekonomikoari alderantziz lotuta dago. Atzeraldi Handian (2008-2013) soldata-arrakala handitu zen bi lurraldeetan (EAEn \% 22.99 izatetik, \% 25.16 izatera; Espainiako estatuan 21.87 eta 23.09, hurrenez hurren). Eta bestetik, errekuperazio ekonomikoaren zantzuak arrakalaren beherakada dakar bai EAEn baita Espainiako estatuan ere; izan ere, epealdiaren amaieran EAEko soldata-arrakalak 23.57 balioa islatzen du, Espainiako estatukoa 21.92ko balioa izanik. Aipatzekoa da Espainiako estatuko zikloari lotutako joera EAEk islatzen duena baino argiagoa dela. Izan ere, eta batez ere 2014-2017 epealdian, EAEn arrakalaren beherakada ez da leuna izan Espainiako estatuan izan den bezala.

Azkenik, soldata-arrakalaren hazkuntza-tasa kalkula daiteke. Horrek joera desberdinak erakusten ditu bi lurraldeetan. Espainiako estatuan soldata-arrakalaren hazkundea izan da positiboa Atzeraldi Handian eta negatiboa, aldiz, errekuperazio ekonomikoaren urteetan. EAEn, kontrara, ezin da patroi argirik identifikatu. Nolanahi ere, bi lurraldeetan aurkitzen dira hazkuntza maximoak 2012 urtean (Espainiako estatuan \% 4.09koa izanik eta \% 8.17koa EAEn) eta nabarmen egin du behera 2014. urterako (\% -3.09 Espainiako estatuan eta \% -4.79 izanik EAEn). Azterturiko epealdia osotasunez hartuz gero, antzematen da EAEn soldata-arrakalaren urteko batez besteko igoeraren balioa \% 2.63koa dela, horren balioa Espainiako estatuan 0.22 izanik.

\footnotetext{
${ }^{5}$ Lanean zehar azaldu den bezala, daturik ezagatik mugatu da epealdia.

${ }^{6}$ Soldata-arrakala Europako testuinguruan lanaldi-partzialari eta okupazio segregazionalari lotuta agertzen da [33].

${ }^{7}$ Begiratu formulak (1), (2), (3) eta (4) metodologia atalean.
} 
Soldata-arrakalak erakusten du EAEn genero berdintasuna urrunago dagoela (Espainiako estatuan baino). Hau da, emakumezkoen eta gizonezkoen soldatak direla eta, bide luzeagoa dauka EAEk genero berdintasuna lortzeko NBEk definitutako 5. GIH betetzeko bidean.

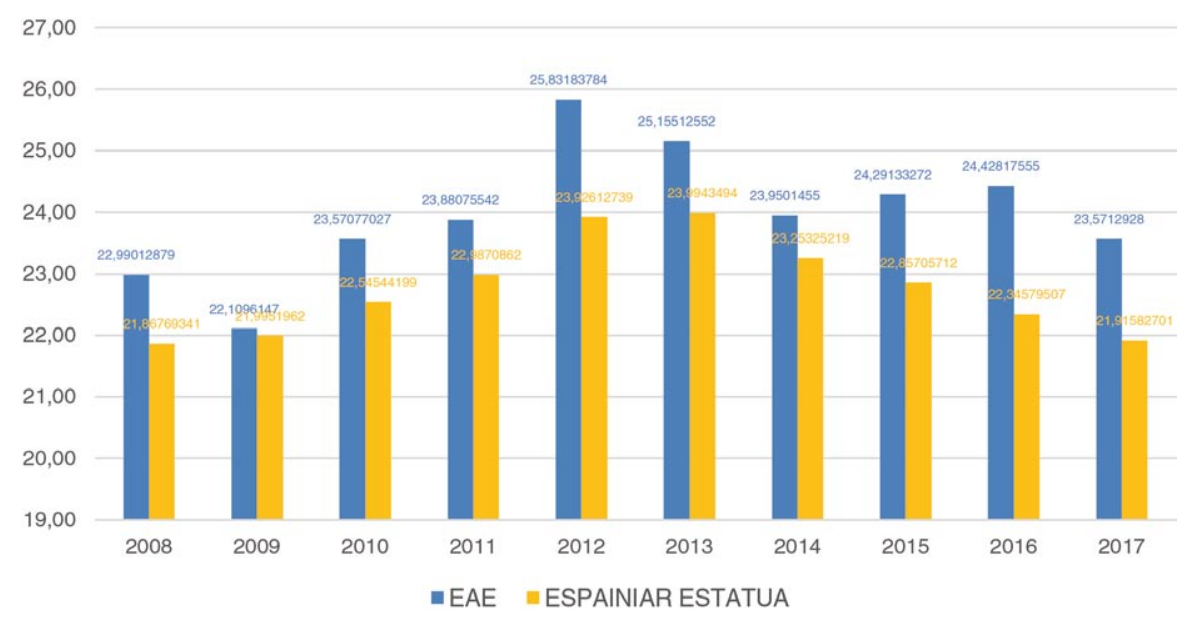

4. irudia. Generoaren araberako Soldata Arrakalaren (SGA) bilakaera EAEn eta Espainiako Estatuan (2002-2020).

\section{EZTABAIDA ETA ONDORIOAK}

Ekarpen honetan NBEk definitutako bosgarren Garapen Iraunkorreko Helburuaren bilakaera aztertzen da EAEko lan merkatuan 2002-2020 epealdian. Genero-arrakala guztien beherakada nabaria da. Horiek dira Langabeziako Genero Arrakala (LGA), Enpleguko / Enpleguaren arloko Genero Arrakala (EGA), Jarduerako arloko Genero Arrakala (JGA) eta Generoaren araberako Soldata Arrakala (SGA).

Aurkitutako beherakadak ziklo ekonomikoaren fase desberdinei lotu ahal zaizkie. Alde batetik, langabezia-arrakalak ziklo ekonomikoaren norabidearen kontra eboluzionatzen $\mathrm{du}$; hau da, atzeraldietan murriztu egiten dira enpleguan dauden desberdintasunak emakume eta gizonen artean, eta hedaldietan zabaldu egiten dira. Horrekin lotuta, enplegu-arrakalak eta jarduera-arrakalak ziklo-ekonomikoaren kontrako bilakaera argia erakutsi ez arren, bai islatzen dute joera kontraziklikoa murriztearen abiaduran; hau da, atzeraldietan arinago murrizten dira, hedaldietan baino. Beste alde batetik, soldata-arrakalaren balioak joera kontrazikliko argia erakusten du; izan ere, soldata-arrakala hedaldietan handitzen da eta atzeraldietan txikitzen da. Emaitza hauek guztiak aurkitzen dira bai EAEn baita Espainiako estatuan ere. 
Lurralde biak alderatzean lau ondorio nagusi atera daitezke: i) EAEko genero-arrakalak Espainiako estatukoak baino txikiagoak direla langabezian, enpleguan eta jardueran; ii) EAEn arrakala guztiak murriztu dira gehiago erlatiboki (hasierako maila abiapuntu harturik) Espainiako estatuan baino; iii) EAEko soldata-arrakala Espainiako estatukoa baino altuagoa da; eta, iv) COVID-19aren garaian aztarnak aurkitzen dira EAEn, Espainiako estatuak oraindik erakutsi ez arren.

Ekarpenak argi islatzen du langabezian izan ezik, non arrakala zero baliotik gertu mugitu den azken urteotan, oraindik lan-merkatuko berdintasuna lortzeko bide luzea duela EAEk. Hau da, 5. GIH lortzeko, agintariek politikak egokitu, garatu eta indarrean jarri behar lituzkete. Bereziki soldata-arrakalari dagozkionetan. Politika horiek guztiek kontutan hartu behar izango lituzkete lan merkatuko ezaugarri konkretuak. Izan ere, artikulu honen hasieran azaldu den bezala, soldata-arrakala faktore mota ezberdinei lotuta dator. Hau da, faktore tradizionalei, faktore berriei (psikologia ikuspuntutik hartutakoak, besteak beste) edota eskaintza, eskaria eta lan-merkatuko instituzioetan oinarritutako faktoreei lotuta. Horien esangura maila neurtzeko eta politika-proposamen konkretuak egiteko, etorkizunean ikerkuntza garatu beharko da.

\section{BIBLIOGRAFIA}

[1] NBE 2020 Garapen Iraunkorreko Helburuak. 5.GIH. Genero Berdintasuna. Nazio Batuen Erakundeak. Egokituta eta euskaratuta UNtik. Kontsulta eginda 2020. Maiatzak. 28.

[2] BRUNET. C. eta JEFFERS. E. 2017. «Labor Market Gender Gaps and the GR: Evidence from European Union». Work in Progress.

[3] PEINADO. P. eta SERRANO. F. 2018. «Gender Inequality in the Labour Market and the Great Recession» in Inequality. Trends. Causes. Consequences. Relevant Policies eds. Arestis P eta Sawyer M : 233-274.

[4] UNFPA 2020 «COVID-19: A Gender Lens. Protecting Sex and Reproductive Health and Rights. and Promoting Gender Equality». Technical Brief. March 2020. United Nations Fund HQ. New York.

[5] BLAU. F. D. eta KAHN. L. M. 1992. «The Gender Earnings Gap: Learning from International Comparisons». American Economic Review, 82, 533-538.

[6] BLAU. F. D. eta KAHN. L. M. 1995. «The Gender Earnings Gap: Some International Evidence». In «Differences and Changes in Wage Structures» edited by Freeman. R. and Katz. L., pp.105-143 . Chicago: University of Chicago Press.

[7] BLAU. F. D. eta KAHN. L. M. 1996a. «International Differences in Male Wage Inequality: Institutions versus Market Forces». Journal of Political Economy, 104, 791-837. 
[8] BLAU. F. D. eta KAHN. L. M. 1996b. «Wage Structure and Gender Earnings Differentials: An International Comparison». Economica, 63, 29-62.

[9] BLAU. F. D. eta KAHN. L. M. 2001. «Understanding International Differences in the 'gender pay gap». NBER. WP 8200.

[10] BLAU. F. D. eta KAHN. L. M. 2013. «Female Labor Supply: Why is the US falling Behind?». NBER WP. 18702.

[11] BLAU. F. D. eta KAHN. L. M. 2017. «The Gender Wage Gap: Extent. Trends. and Explanations». Journal of Economic Literature, 553, 789-865.

[12] KIDD. M.P. eta SHANNON. M. 1996. «The Gender Wage Gap: A comparison of Australia and Canada». Industrial and Labour Relations Review, 49, 729-746.

[13] KUNZE. A. 2017. «The Gender Wage Gap in Developed Countries». CESifo WP.6529.

[14] OLIVETTI. C. eta PETRONGOLO. B. 2008. «Unequal pay or unequal employment? A cross-country analysis of gender gaps». Journal of Labor Economics, 264, 621-654.

[15] GOLDIN. C.. LAWRENCE. F. K. eta KUZIEMKO. I. 2006. «The homecoming of American College Women: The Reversal of the College Gender Gap». Journal of Economic Perspectives, 204, 133-156.

[16] JUHN. C. eta MURPHY. K. M. 1997. «Wage Inequality and Family Labour Supply». Journal of Labour Economics, 15 I, 72-97.

[17] BLAU. F. D. eta KAHN. L. M. 2007. «Changes in the Labor Supply Bahaviour of Married Women:1980-2000». Journal of Labour Economics, 253, 393-438.

[18] HECKMAN. J.J. 1979. «Sample Selection Bias as a Specification Error». Econometrica, 471, 153-161.

[19] BLAU. F. D.. FERBER. M. A. eta WINKLER. A. E. 2014. Economics of Women. Men and Work. $7^{\text {th }}$ Edition. Pearson.

[20] BLAU. F. D. eta KAHN. L. M. 2013b «The Feasibility and Importance of Adding Measures of Actual Experience to Cross-Sectional Data Collection». Journal of Labour Economics, 312 part 2, 17-58.

[21] GOLDIN. C. 2014 «A Grand Gender Convergence: Its Last Chapter». American Economic Review, 104 4, 1091-119.

[22] KEITH. K. eta MCWILLIAMS. A. 1995. «The Wage Effects of Cumulative Job Mobility». ILR Review, 491, 121-37.

[23] ALABANESI. S. eta OLIBETTI. C. 2009. «Home Production. Market Production and the Gender wage Gap: Incentives and Expectations». Review of Economic Dynamics, 12 1, 80-107.

[24] CORREL. S. BERNARD. S. eta PAIK. I. 2007. «Getting a Job: Is There a Motherhood Penalty?». American Journal of Sociology, 112 5, 1297-338.

[25] EC 2018. «Tackling discrimination at work». European Commission. Employment. Social Affairs and Inclusion. Eskuragarri: https://ec.europa.eu/social/main.jsp?catId=158\&langId=en. Kontsulta eginda: 2020/06/03. 
[26] BECKER. G.S. 1971. The Economics of Discrimination. Second Edition. Chicago and London: University of Chicago Press.

[27] BERTRAND. M. 2011. «New Perspectives on Gender». In Handbook of Labour Economics 4B. eds. Ashenfelter. O eta Card. D. 1543-90. Amsterdan eta Boston: Elsevier. North-Holland.

[28] CROSON. R. eta GNEEZY. U. 2009. «Gender Differences in Preferences». Journal of Economic Literature, 472, 448-474.

[29] MUELLER. G. eta PLUG. E. 2006. «Estimating the Effect of Personality on Male and Female Earnings». ILR Review, 60 1, 3-22.

[30] Jhun, Murphy eta Pierce, 1993. «Wage Inequality and the Rise in Returms to Skill». Journal of Political Economy, 101, 410-442.

[31] BERTOLA. G.. BLAU. F.D. eta KHAN. L.M. 2007. «Labour Market Institutions and Demographic Employment Patterns». Journal of Population Economics, 204, 833-867.

[32] JABA. E. PÂRTACHI. I. CHISTRUGA. B. eta BALAN. C.B. 2015. «Gender Employment Gap in EU before and after the crisis». Procedia Economics and Finance, 20, 326-333.

[33] BOLL. C.. ROSSEN. A. eta WOLF. A. 2016. «The EU Gender Earnings Gap: Job Segregation and Working Time as Driving Factors». Hamburg Institute of International Economics HWWI RP176. 
